\title{
TREATMENT OF OBESITY: NEWER PERSPECTIVES
}

\author{
Abhyuday Verma1, Deepika Verma ${ }^{2}$ \\ ${ }^{1}$ Consulting Endocrinologist, Department of Endocrinologist, Superspeciality Endocrinology and Women Care Clinic, Palasia. \\ ${ }^{2}$ Consulting Gynaecologist, Department of Gynaecologist, Superspeciality Endocrinology and Women Care Clinic, Palasia,
}

\begin{abstract}
Obesity is a serious health problem worldwide and has reached epidemic proportions. It increases the risk of diabetes, ischemic heart disease, some cancers, infertility, menstrual disorders, etc. Various medications along with lifestyle changes have been tried by health providers and patients to reduce weight but with limited success. Now we have newer incretin class of drugs which have potential to reduce weight along with metabolic advantages. We used injectable incretin therapy in our obese patients and the results were encouraging. This class of drug in future may provide a better option for patients willing to lose weight.
\end{abstract}

\section{KEYWORDS}

Obesity, Weight Reduction, Incretins, GLP-1.

HOW TO CITE THIS ARTICLE: Verma A, Verma D. Treatment of obesity: newer perspectives. J Evolution Med Dent Sci 2016;5(2):112-113, DOI: 10.14260/jemds/2016/27

\section{INTRODUCTION}

Obesity is a serious health problem worldwide. It increases the risk of diabetes, ischemic heart disease, specific cancers, infertility, menstrual disorders etc.

Earlier several trials have shown that with lifestyle changes and medications, weight loss is not easily accomplished or maintained. Meta-analyses of clinical trials on non-pharmacological strategies for weight reduction have reported 1-6kg losses that have been difficult to maintain.

Various drugs like sibutramine and orlistat trials reported average weight reductions of $3-5 \mathrm{~kg}$, but had high dropout rates that were possibly due to adverse events, suggesting that the interventions could be less effective in clinical practice. Meta-analyses have found that bariatric surgery reduces long-term mortality in obese patients, but the safety, risks and costs of this intervention limit the use for large patient populations.[1]

In the present scenario, to fight against the obesity epidemic, we require a drug with less side effect, faster action and metabolic advantages. The injectable incretin are there in market and these promise good glycemic control in diabetic patients, along with various other benefits. ${ }^{[2]}$ The US Food and Drug Administration (FDA) has approved the diabetes drug liraglutide (GLP-1 analogue) for the treatment of obesity.

The specific indication is along with lifestyle for chronic weight management in individuals with a body mass index of $30 \mathrm{~kg} / \mathrm{m}^{2}$ or greater (Obesity) or $27 \mathrm{~kg} / \mathrm{m}^{2}$ or greater (Overweight) in the presence of at least one weight-related comorbidity such as hypertension, diabetes, or dyslipidemia. ${ }^{[3]}$

In response to the review article by Gupta, "Pleiotropic effects of incretins," we conducted a small prospective study to see benefits with injectable incretin liraglutide. This drug was earlier used for control of hyperglycemia in type 2 diabetes and recently is been approved for only weight reduction too.

Financial or Other, Competing Interest: None.

Submission 10-12-2015, Peer Review 11-12-2015,

Acceptance 01-01-2016, Published 05-01-2016.

Corresponding Author:

Dr. Abhyuday Verma

5/1, Pardeshipura,

Indore-452003,

Madhya Pradesh

E-mail: abhyudaya76@yahoo.com

DOI:10.14260/jemds/2016/27
Fifty patients from the Obesity Clinic of our centre, with metabolic syndrome like obesity, hypertension, high triglycerides, pre-diabetes etc. willing to take liraglutide, were started on daily subcutaneous injection of $0.6 \mathrm{mg}$ initially for a week and later on the dose was increased to $1.2 \mathrm{mg}$ per day.

Other than few minor side effects like headache and nausea in few patients which lasted for a few days after initiation, none of the patients had any other complaints. Three patients required a dose of $1.8 \mathrm{mg} / \mathrm{dl}$ of liraglutide to achieve desirable results of weight loss.

Baseline weight of patients was $105 \mathrm{~kg}( \pm 12.5 \mathrm{~kg})$ and waist circumference was $112 \mathrm{~cm}( \pm 8.1 \mathrm{~cm})$. M: $F$ ratio was $2: 3$, age of the patients was 32 years ( \pm 10.2 years), and $62 \%$ of the patients had family history of diabetes and hypertension. The other parameters were: fasting blood sugar (FBS) $104 \mathrm{mg} / \mathrm{dl}$ $( \pm 8 \mathrm{mg} / \mathrm{dl})$, blood pressure $138 / 90 \mathrm{~mm}$ of $\mathrm{Hg}( \pm 15.4 / 6.3)$ and total cholesterol $205 \mathrm{mg} / \mathrm{dl}( \pm 14.3 \mathrm{mg} / \mathrm{dl})$, triglycerides 166 $\mathrm{mg} / \mathrm{dl}(+12.2 \mathrm{mg} / \mathrm{dl})$.

\section{RESULTS}

After 12 weeks of subcutaneous liraglutide $1.2 \mathrm{mg} / \mathrm{dl}$ therapy, weight loss mean was $10 \mathrm{~kg}( \pm 2.8 \mathrm{~kg})$, waist circumference reduction $4.1 \mathrm{~cm}( \pm 1.6 \mathrm{~cm}), \mathrm{FBS} 96 \mathrm{mg} / \mathrm{dl}( \pm 6 \mathrm{mg} / \mathrm{dl})$, total cholesterol $184 \mathrm{mg} / \mathrm{dl}( \pm 6 \mathrm{mg} / \mathrm{dl})$, serum triglycerides 134 $\mathrm{mg} / \mathrm{dl}(+12 \mathrm{mg} / \mathrm{dl})$, and blood pressure was $124 / 86 \mathrm{~mm}$ of $\mathrm{Hg}$ $( \pm 12.2 / 5.1)$.

In only one female patient, there was no weight reduction, although other metabolic parameters improved.

\section{DISCUSSION}

Incretins are gut-derived hormones, secreted in response to nutrient ingestion, that potentiate insulin secretion from islet $\mathrm{B}$ cells in a glucose-dependent fashion, and lower glucagon secretion from islet A cells. There are two predominant incretins: Glucagon-like peptide-1 (GLP-1) and GlucoseDependent Insulinotropic Peptide (GIP) (Also known as gastric inhibitory peptide). Incretin effect is impaired in type 2 diabetes, known as GLP-1 deficiency.

Circulating GLP-1 has many beneficial effects on glucose metabolism. They increase insulin secretion to maintain glucose homeostasis and reduce glucagon secretion. This leads to reduction in postprandial glycemic.

These also reduce gastric emptying and increase satiety due to delayed gastric emptying. They also reduce food 
ingestion due to effects on brain. These effects help the patient lose weight along with sugar control. Animal studies have shown GLP-1 increases B cell number and increases B cell mass. Along with this they increase B cell proliferation, islet neogenesis and reduce their apoptosis. $[4,5,6]$

Obesity-related diseases have an impact on the individuals' quality of life, and managing their complications puts an extra burden on his pocket. Accordingly, identification of effective interventions for weight reduction is crucial. We gave subcutaneous liraglutide, a GLP-1 receptor agonist to our obese patients with metabolic syndrome.

These patients were at risk of developing diabetes, hypertension and other weight related diseases. Our intervention along with a healthy lifestyle resulted in improved metabolic parameters along with weight loss, which may decrease the future risk of various complications.

\section{CONCLUSION}

Liraglutide leads to significant weight loss in obese and overweight patients. These patients had earlier tried lifestyle changes but were unsuccessful. Along with weight loss, additional beneficial effects on blood pressure and lipids might be achieved due to the pleiotropic effects of liraglutide. Further well-planned studies are needed to elucidate the effects of glucagon like peptide 1 receptor agonists in the treatment of obese individuals without diabetes.

\section{ACKNOWLEDGEMENT}

We acknowledge our staff dietician, physiotherapist for patient counseling and receptionist for data management.

\section{REFERENCES}

1. Vilsbøll T, Christensen M, Junker AE, et al. Effects of glucagon-like peptide-1 receptor agonists on weight loss: Systematic review and meta-analyses of randomised controlled trials. BMJ 2012; 344:d7771.

2. Astrup A, Rössner S, Van Gaal L, Rissanen A, Niskanen L, Al Hakim $M$, et al. Effects of liraglutide in the treatment of obesity: A randomised, double-blind, placebo-controlled study. Lancet. 2009;374:1606-16.

3. Bray GA, Ryan DH. Update on obesity pharmacotherapy. Ann N Y Acad Sci 2014; 1311:1-13.

4. Ranganath LR. Incretins: Pathophysiological and therapeutic implications of glucose-dependant insulinotropic polypeptide and glucagon-like peptide-1. J Clin Pathol. 2008; 61:401-409.

5. De Mello AH, Pra M, Cardoso LC, et al. Incretin-based therapies for obesity treatment. Metabolism 23 May 2015.

6. Prasad-Reddy L, Isaacs D. A clinical review of GLP-1 receptor agonists: efficacy and safety in diabetes and beyond. Drugs Context 2015; 4:212283. 